\title{
IV
}

\section{MARRIAGE AND SYPHILIS}

Discussion after Addresses by Dr. Lacapère and Dr. R. C. Jewesbury.

Dr. J. H. Sequeira said he had listened with the greatest interest to the communications, and had read with equal interest the account of the discussion of the same subject at the Society's previous meeting. The incidence of syphilis after marriage he regarded as a point of great importance, and on it he wished to communicate some observations made by his friend, Dr. Palmer, now chief obstetrician at King's College Hospital, formerly of the London. Dr. Palmer had collected statistics regarding over 2,000 primiparæ whom he had seen in the antenatal clinic of London Hospital and in neighbouring institutions. Wassermann tests in that number showed a positive reaction in only about 2 per cent. That figure should be borne in mind, as he, the speaker, thought the danger of communicating the disease in the early months of marriage had been somewhat exaggerated by propagandists. Admittedly, however, the figure did not cover the whole of the infections, as there was a grave danger, in syphilis, of miscarriages and still-births. In his experience, a large number of women were infected after marriage ; there was a history of one, perhaps two, children born healthy, followed by a series of miscarriages, or the children born showed evidences of congenital syphilis.

He did not think members could do better than follow the advice given by Dr. Lacapère in regard to treatment. But a practical difficulty was the following: What was to be done with the syphilitic who had a positive Wassermann and who proposed to get married ? This question frequently came up. There were patients who had had what might be considered adequate treatment, i.e., several series of intravenous injections of potent arsenical remedies, followed by courses of mercury, yet the Wassermann reaction could not be rendered permanently negative. Should marriage be approved in such cases? Duration of time since infection was an important matter. Sir Jonathan Hutchinson used to say that " time as well 


\section{MARRIAGE AND SYPHILIS}

as mercury tended to cure syphilis." All knew cases in which treatment had been either nil or of small amount, and yet after a long time healthy children were procreated. That day he saw a patient who was inadequately treated for syphilis early in the century. In I9I2 arsenical remedies were administered, and he had a long-continued series of them, but his Wassermann was never negative. He was permitted to marry, being informed of the risks to himself arising from his condition, and he shortly afterwards developed angina pectoris.

In cases of this kind two standpoints needed to be considered. The first was that of public health, i.e., was such patient liable to transmit the disease to other people? With adequate treatment such transmission might be prevented, and ante-natal treatment might ensure that the mother would have healthy children. The second standpoint was that of life insurance. This related to cases in which, although there had been adequate treatment and a patient might be assured he was likely to have healthy children, he could not be considered a sound life, and as such must be warned of his danger.

Dr. Jewesbury's communication bore out what he, the speaker, had long advocated, ante-natal treatment of syphilitic women. In IgI 8 he introduced at a meeting of medical men forty-five children of syphilitic mothers who had been free from any taint of syphilis during the antenatal period. As a result of being followed up there was no sign of congenital syphilis among them. He would like Dr. Jewesbury to furnish approximately the numbers of children in each of the age-categories of which he spoke. In his own experience the group of infants up to twelve months was a small one.

Dr. A. C. Palmer said the number of primiparæ in his series was 2,010, and those with a positive Wassermann were only $2 \mathrm{I}$. Of these $2 \mathrm{I}$ young women, $\mathrm{I} 5$ were delivered of living babies. Of the remaining 6,4 did not continue to attend, I died, I was delivered of a still-born child. Autopsy showed no evidence of syphilis in the case of the deceased mother; autopsy could not be obtained in the case of the still-born child. Nine husbands came for Wassermann reaction; all were negative; the remaining husbands refused examination. Of the 2I primiparæ, I3 had anti-syphilitic treatment before delivery. Only two showed physical signs of syphilis; one had congenital 


\section{BRITISH JOURNAL OF VENEREAL DISEASES}

interstitial keratitis, the other had large perineal condylomata.

Only two babies had positive Wassermann reaction immediately after delivery. One baby was negative in four months, the other was still positive in spite of treatment.

The primiparæ in this series consisted of women who came to the hospital in the ordinary way for treatment during confinement.

The number of positive Wassermann reactions is strikingly small, namely, 2I out of a total of 2 ,oro primiparæ : I.04 per cent.

Mr. H. WAnsey Bayly said that in this matter the important matter to consider was the proportion of risk. If all and every kind of risk of death or disablement had to be eliminated before marriage was permitted, no marriage would ever take place. Life consisted of a series of risks. Their French colleague did not say that marriage should only be permitted when there was no risk whatever and that treatment must be carried out for five or ten years before marriage could be permitted. The point was that no undue risk should be run. Both the opening papers seemed to show that if the parents received adequate treatment there was but little danger of their children developing syphilis. There seemed to have been a tendency to exaggerate the risks of syphilitic infection ; he saw no reason why marriage should not be permitted if the persons concerned had received a comparatively short course of antisyphilitic treatment first, and were willing to continue with it after marriage. He had given his consent to marriage of a number of patients after only one year of treatment, the treatment having been continued after the marriage ; and, so far, such marriages had not produced either syphilitic children or domestic unhappiness.

Dr. Henry MacCormac said he had been very pleased to hear Dr. Lacapère's definite rules for the treatment of syphilis. The problem of special difficulty was that of the individual who, though treated, still gave a positive Wassermann. Should such a person marry ? In the case of a man in these circumstances, if the syphilis was of long enough standing, marriage might take place, but not in the case of a woman. At such a late stage a man could not give to his wife the disease, so that if the mother was 


\section{MARRIAGE AND SYPHILIS}

not herself infected with syphilis she would have healthy children. He was aware that Dr. Darier said that in those cases some definite evidence of ill-health would be found in the children. A woman with chronic syphilis could communicate it to her children, though not to her husband. Still, if she underwent ante-natal treatment she might be given permission to marry. He used to think that seven years was a fairly safe time. One such patient, however, in whom treatment had been somewhat irregular, married, and for a year all was satisfactory, but at the end of that time she had well-marked syphilis in the secondary stage. Often in these cases one could not be sure whether it was contracted from the husband.

Dr. LACAPÈRE, in reply, said it was not possible to furnish exact rules as to when marriage should be permitted after syphilis ; one could only give general guidance for nonspecialist practitioners. It must always be borne in mind that if prohibition of marriage were extended over too long a time, patients would go against the rules and would marry much earlier than was safe. The rules indicated in his paper had been published in France, in the Bulletin of the French Society for the Study of Venereal Diseases, in which Society French medical men studied them. As to the cases of long-standing syphilis, with a persistently positive Wassermann, the danger in such cases was lest they develop general paralysis. When the syphilis was less than about twelve years old it was dangerous to allow even a man to marry, and a woman should not be allowed to marry at all so long as she gave a positive Wassermann.

Dr. Jewesbury, in reply, said that in the first of the age-groups he gave, namely children up to one year old, there were about I20. In the second group, of one to six years, the number was about thirty, and in the third series, aged six to fourteen years, there were about ninety. 